\title{
Dynamics of nutrient cycling and related benthic nutrient and oxygen fluxes during a spring phyto- plankton bloom in South San Francisco Bay (USA)
}

\author{
Christian Grenz $^{1, *}$, James E. Cloern ${ }^{2}$, Stephen W. Hager ${ }^{2}$, Brian E. Cole ${ }^{2}$ \\ ${ }^{1}$ Université de la Méditerrannée CNRS UMR 6535, LOB, rue de la Batterie des Lions, 13007 Marseille, France \\ ${ }^{2}$ U.S. Geological Survey, MS496, 345 Middlefield Road, Menlo Park, California 94025, USA
}

\begin{abstract}
Benthic oxygen uptake and nutrient releases of N, P and Si were measured weekly at 2 sites in South San Francisco Bay around the 1996 spring bloom. Exchanges across the sediment-water interface were estimated from whole core incubations performed in the laboratory at in situ temperature and in dark. Fluxes changed significantly on a weekly time scale. Over a period of $15 \mathrm{wk}$ the fluxes of dissolved inorganic N, P and Si ranged from -40 to $+200,0$ to 13 and from 30 to $400 \mu \mathrm{mol} \mathrm{m} \mathrm{m}^{-2} \mathrm{~h}^{-1}$ respectively. Sediment oxygen demand increased from 10 before to $64 \mathrm{mg} \mathrm{O}_{2} \mathrm{~m}^{-2} \mathrm{~h}^{-1}$ just after the bloom period. During the bloom, nutrient fluxes represented about 20,16 and $9 \%$ of the $\mathrm{Si}, \mathrm{P}$ and $\mathrm{N}$ requirements for primary production. Before and after the bloom period, Si fluxes contributed up to 30 and $>100 \%$ of this requirement and $\mathrm{P}$ and $\mathrm{N}$ fluxes up to 15 and $50 \%$ respectively. Simple empirical models explain most of the spatial-temporal variability of benthic fluxes of $\mathrm{Si}_{4} \mathrm{P}$ and $\mathrm{NH}_{4}$ (but not $\mathrm{NO}_{3}$ ) from 3 predictor variables: sediment porosity, nutrient concentration in bottom waters and chlorophyll content of surficial sediments. These models show that algal blooms influence benthic-pelagic nutrient exchange through 2 processes: (1) depletion of nutrients from the water column (which enhances gradient-driven transports across the sediment-water interface) and (2) sedimentation of labile phytodetritus (which promotes remineralization in or on the surficial sediments). Rates and patterns of nutrient cycling were very different at the shallow and deep study sites, illustrating the challenge of extrapolating measurements of coupled algae-nutrient dynamics to whole ecosystems.
\end{abstract}

KEY WORDS: Estuaries $\cdot$ Benthic fluxes $\cdot$ Nutrient cycling $\cdot$ Pelagic-benthic coupling $\cdot$ San Francisco Bay

\section{INTRODUCTION}

Intensive studies of shallow coastal ecosystems have in recent decades shown the complexity of the couplings between biogeochemical processes in the benthos and water column. Pelagic production in these systems is stimulated by nutrient inputs from the watershed (Kemp \& Boynton 1984) or upwelling of offshore waters (Taylor 1992) and coupled to benthic production in both marine and freshwater ecosystems (Johnson \& Wiederholm 1992, Goedkoop \& Johnson 1996, Miller-Way \& Twilley 1996). Benthic-pelagic coupling works in both directions: sediment nutrient fluxes fuel primary production in the water column (Nixon et al. 1976, Callender \& Hammond 1982), and

•E-mail: grenz@com.univ-mrs.fr cycles of production in the water column provide pulsed inputs of labile organic substrate for regeneration in sediments. A substantial proportion (10 to $50 \%$ ) of pelagic primary production can sink to the bottom (Hargrave 1973, Nixon 1981, Jørgensen 1983, Olesen \& Lundsgaard 1995) at relatively high rates (Alldredge \& Gotschalk 1989, Tiselius \& Kuylenstierna 1996) Conversely, resuspension of dissolved nutrients and inorganic and organic particles including resting cysts influence pelagic production (Sondergaard et al. 1992, MacIntyre \& Cullen 1996, Marcus \& Boero 1998).

Field observations and (mostly) laboratory experiments have shown large changes in benthic nutrient regeneration and release in response to algal blooms (Graf et al. 1982, Jensen et al. 1990, Hansen \& Blackburn 1992, Overnell et al. 1995, Andersen 1996). For instance, Kelly \& Nixon (1984) reported an immediate 
benthic response to a pulsed input of organic matter in a mesocosm, and they concluded that $80 \%$ of the annual $\mathrm{C}$ and $\mathrm{N}$ deposition may be remineralized and returned to the overlying water. Hansen \& Blackburn (1992) similarly observed rapid responses of enhanced oxygen and nutrient fluxes in sediments following additions of algal biomass to simulate deposition of a phytoplankton bloom; they calculated a 'half-life' of 2 to $3 \mathrm{wk}$ for the benthic mineralization of algal-derived organic matter. The benthic response to blooms depends on the magnitude of the sedimentation flux (Hall et al. 1992) and on the quality of the settled seston (Tuominen et al. 1996). Nutrient fluxes at the sediment-water interface can influence or regulate the nutrient composition of the water column since the sediments can behave as either a sink or a source of inorganic nitrogen, phosphorus and silicate through different biogeochemical processes (Nixon et al. 1976 , Billen 1978). Nutrient regeneration in the sediment supplies a large proportion of the phytoplankton nutrient demand during some periods of the year (Fisher et al. 1982, Koop et al. 1990, Cowan \& Boynton 1996). For instance, release of inorganic nitrogen from sediments supplied $22 \%$ of the $\mathrm{N}$ required to support primary production in the Wash estuary (Trimmer et al. 1998) and from 30 to over $100 \%$ in Danish coastal areas (Blackburn \& Henriksen 1983).

Previous work in South San Francisco Bay (Hammond et al. 1985; Caffrey 1995; Caffrey et al. 1996) has established that there are seasonal variations in benthic nutrient fluxes in this estuary. However, there is insufficient temporal coverage to enable an evaluation of benthic-pelagic transfer related to the spring bloom. We present here results of a study designed to measure weekly changes in the water column and sediments of South San Francisco Bay, a coastal embayment with a large and somewhat predictable spring phytoplankton bloom (Cloern 1996). Our study was designed to determine if the cycling patterns observed in microcosms (rapid transformation of nutrients from solution into particles into sediments and then back to solution) occur in this shallow coastal ecosystem. We ask here 2 questions: (1) How do nutrient fluxes from sediments to water vary on a weekly time scale in response to an event of rapid phytoplankton population growth and nutrient uptake? (2) Are the patterns of coupled pelagic-benthic nutrient cycling different in deep and shallow habitats, which are known to have different balances between production and consumption processes? We know, for example, that net primary production is higher in the shallow domains than in the deep channels of South San Francisco Bay (Cloern et al. 1985). The strength of pelagic-benthic coupling could also be higher in shallow domains where the effects of benthic nutrient regeneration are distributed over a small water-column height. A second aspect of our experimental design was to compare the weekly scale changes in nutrient fluxes in the shallow and deep domains of this estuary.

\section{STUDY DESIGN AND METHODS}

Study sites. South San Francisco Bay is a tidal, lagoon-like estuary characterized by 2 topographical areas: a broad subtidal shoal region with mean-tide depths $<2 \mathrm{~m}(80 \%$ of South Bay surface area), and a longitudinal channel with depths up to about $25 \mathrm{~m}$. These 2 bathymetric domains have distinct features of primary production and net ecosystem metabolism: the shallow domains are net autotrophic while the deep channel domains are net heterotrophic (Caffrey et al. 1998). Tidal current speeds (up to $0.8 \mathrm{~m} \mathrm{~s}^{-1}$ ) are proportional to the mean water depth, and spring-neap variations are pronounced (Walters et al. 1985). Spring diatom blooms are prominent features of the seasonal dynamics of South San Francisco Bay, and nutrient recycling plays a fundamental role in phytoplankton dynamics because dissolved $\mathrm{N}$ and $\mathrm{Si}$ are depleted during the spring blooms of some years (Cloern 1996). The spring phytoplankton bloom persists for a few weeks or months, and it provides a significant fraction of the annual phytoplankton production (Cloern 1984) and therefore of the potential input of organic matter to the sediments. We selected 2 sampling sites (Fig. 1), 1 representative of the deep channel habitat (Channel Station $-15 \mathrm{~m}$ depth at mean tide level) and 1 representative of the subtidal shallow habitat (Shoal Station $\sim 2$ m mean depth).

Sampling strategy and analysis. Weekly hydrographic surveys were conducted along a south-north channel transect to map distributions of salinity and temperature (by CTD), chlorophyll a (chl a) (fluorometer), dissolved oxygen (electrode) and light penetration (submersible quantum sensor). Gross primary productivity was estimated from profiles of chlorophyll and light, using previously determined photosynthesis-irradiance curves (details are given by Caffrey et al. 1998). Phytoplankton species composition and biomass (as biovolume) were determined on samples preserved with acidified Lugol's solution and examined with an inverted microscope. Additional samplings were performed weekly at the channel and shoal study sites by collecting water samples $1 \mathrm{~m}$ beneath the surface (Niskin bottle) and $0.5 \mathrm{~m}$ above the bottom (peristaltic pump). These samples were maintained at ambient temperature and in the dark during transit to the laboratory for analyses and use in core-incubation experiments (below). Chl a concentrations were measured using the spectrophotometric method of Strickland \& Parsons (1972). 
Sediment cores (12 cm diameter) were sampled with a gravity corer, weekly between 6 February and 14 May 1996. Cores were taken at high slack tide to minimize the tidally induced disturbance of the sediment surface. In order to obtain measurable fluxes, cores were incubated over periods of 6 to $25 \mathrm{~h}$ during the (presumed) linear release or uptake phase. Three replicate cores from each site were incubated at field temperature in darkness with mild agitation to prevent development of concentration gradients in the overlying water. Samples of the overlying water were pumped from the core tubes for nutrient and oxygen analyses at $2 \mathrm{~h}$ intervals, 4 times the first day and twice the following day. Water removed from the core was replaced with bottom water. This resulted in a $<1 \%$ dilution of the overlying water

Water sub-samples for oxygen analysis (unfiltered in $7 \mathrm{ml}$ glass bottles) were fixed immediately and analyzed within a few hours with an automated titration system (Metrohm $686^{\mathrm{TM}}$ ) using the potentiometric titration method of Granéli \& Granéli (1991). All other sub-samples were filtered through pre-rinsed glass fiber filters (Whatman GF/F). Samples for determination of nitrite $\left(\mathrm{NO}_{2}\right)$, nitrate $\left(\mathrm{NO}_{3}\right)$, ammonium $\left(\mathrm{NH}_{4}\right)$, phosphate (DRP) and silicate (Si) were usually refriger-

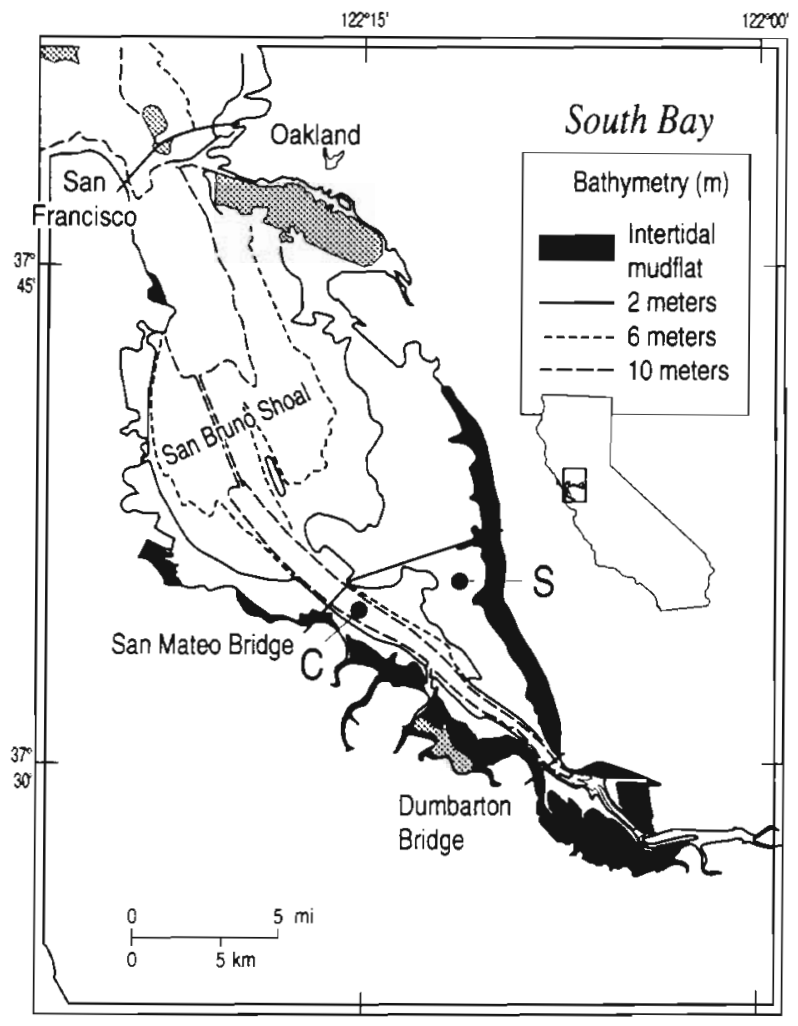

Fig. 1. Map of South San Francisco Bay, showing locations of the sampling sites in the deep channel (C) and lateral, subtidal shallows $(\mathrm{S})$
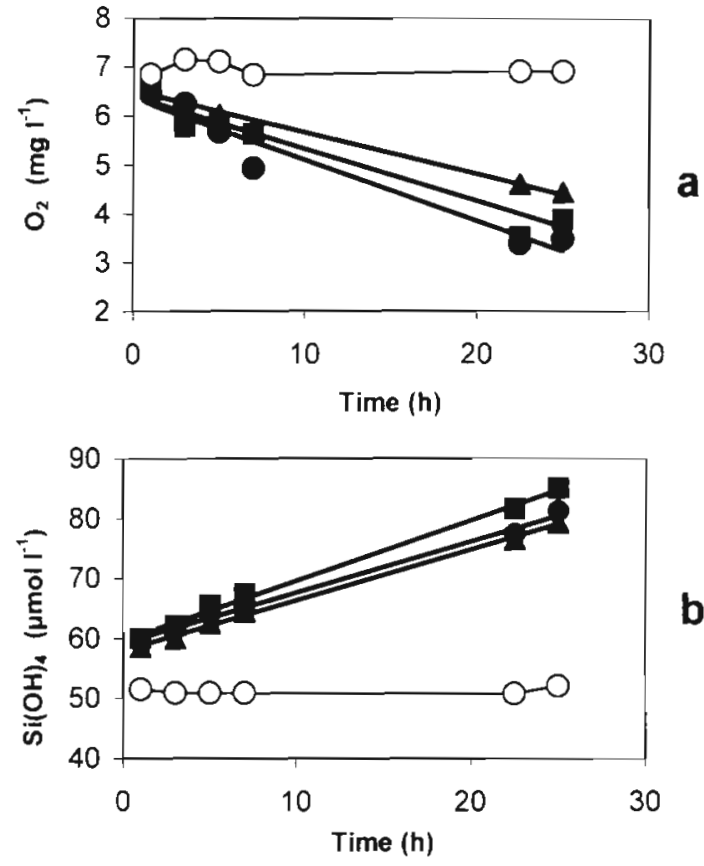

Fig. 2. Time series of (a) oxygen and (b) silicate concentrations from incubation of triplicate cores $(\boldsymbol{\Lambda}, \mathbf{0})$ taken from the channel station on 5 May 1996. Regression lines are given in bold (see 'Sampling strategy and analysis'). (O) Concentrations in the reservoir of replacement water

ated overnight and analyzed with a Technicon II autoanalyzer the next day. Samples from 19 March, 15 April and 5 May were frozen at $-20^{\circ} \mathrm{C}$ and analyzed within $11 \mathrm{~d}$ of collection. Sub-samples of surface sediments ( $3 \mathrm{~cm}$ height and $1.5 \mathrm{~cm}$ diameter) were taken from each core at the end of the flux experiments for analysis of porosity, pigment concentration and biogenic silicates. Porosity was determined using percent water content and assuming a sediment density of $2.56 \mathrm{~g} \mathrm{~cm}^{-3}$. Sediment chl $a$ and pheopigments were analyzed by spectophotometry following acetone extraction as in Caffrey et al. (1996). Biogenic silica was estimated from the amorphous silica content of the sediments, measured using the time-course method (e.g. DeMaster 1981), with $0.2 \mathrm{~N} \mathrm{NaOH}$ as the digestion reagent. For macrobenthic fauna determination, each core was then sieved on a 200 micron mesh, and the animals were preserved in $10 \%$ formalin for identification and wet weight determination.

After correction for water column changes, rates of nutrient and oxygen exchange across the sedimentwater interface were calculated as slopes of linear regressions of nutrient or oxygen concentration against time. Areal fluxes were calculated by multiplying the rates of concentration change times the water height in each core tube. As an example, Fig. 2 shows a time series of oxygen and silicate obtained during incuba- 

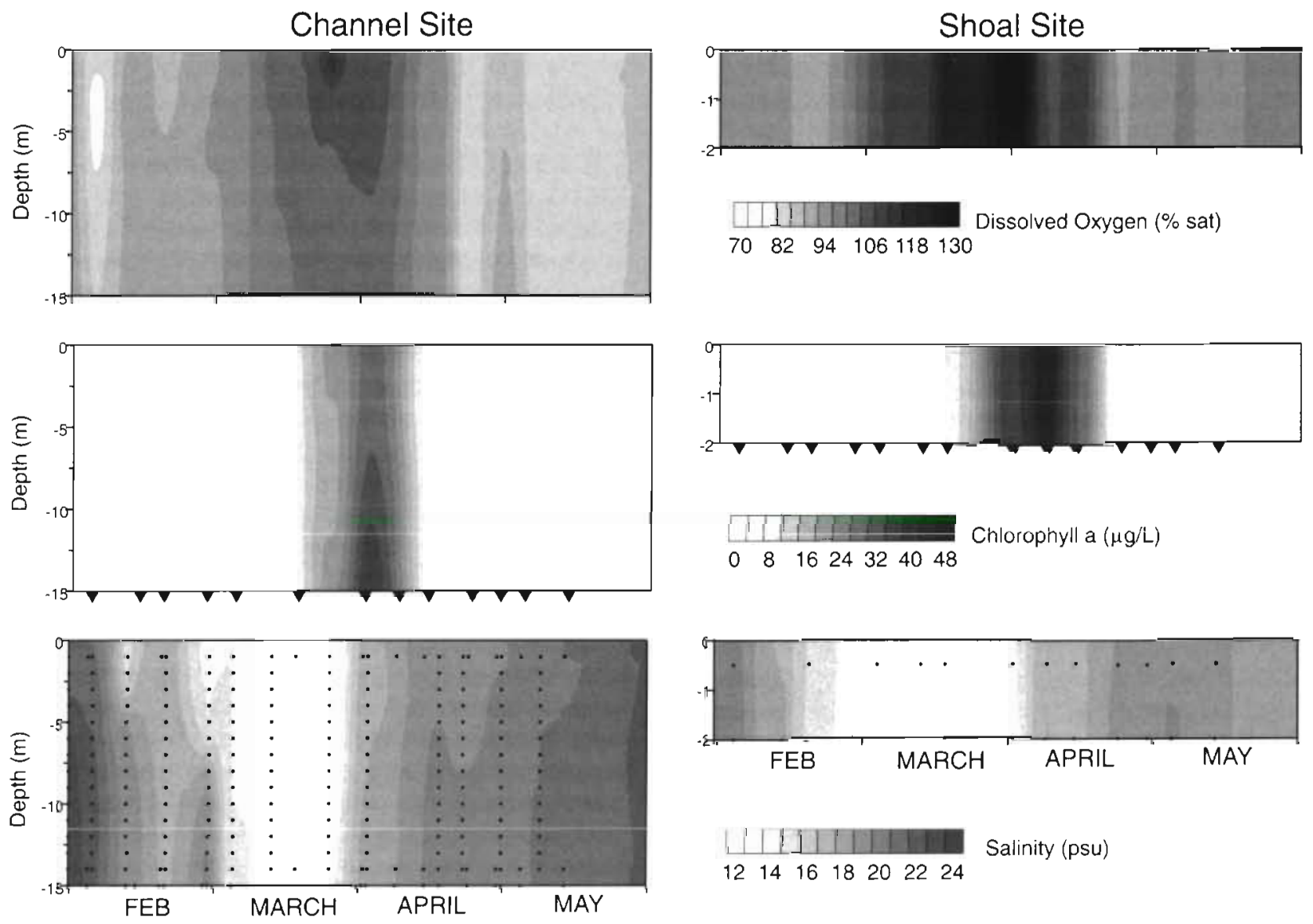

Fig. 3. Vertical contours of dissolved oxygen (as percent saturation), chl a and salinity during the 15 wk study period from February to mid-May 1996. Greyscale images show concentration changes over depth and time, at the deep, channel site (left panels) and at the lateral, shoal site (right panels). Small dots in the lower panels show the distribution of measurements used for interpolation (kriging) to generate these shaded images. Inverted triangles show the times that cores were collected at the channel and shoal site for determination of benthic nutrient fluxes

tion of the triplicate cores collected on 5 May. Fluxes were calculated by multiplying each slope (regression line, $\mathrm{r}^{2}$ between 0.94 and 0.97 ) by the corresponding water height (between 0.33 and $0.36 \mathrm{~m}$ ). We report here mean fluxes and standard deviations from the 3 replicate measurements made at each site.

\section{RESULTS}

\section{Hydrography and algae-nutrient dynamics during the spring of 1996}

The lower reach of South San Francisco Bay is strongly influenced by inputs from the local watershed, and salinity fluctuated in response to a series of storms that carried runoff into the estuary during February and March. At the channel site, salinity was 21 psu at the start of the sampling program in early February.
Salinity was diluted to a minimum of 12.7 psu in late March, and then it returned to 21 psu by the end of the study period in mid-May (Fig. 3). Inputs of freshwater can induce salinity stratification, and persistent stratification can stabilize the water column and trigger phytoplankton blooms in the channel (Koseff et al. 1993). We observed rapid growth of phytoplankton biomass from mid-March to early April, when chl a increased from pre-bloom concentrations of -2 to $3 \mathrm{mg}$ $\mathrm{m}^{-3}$ to maximum concentrations of $55 \mathrm{mg} \mathrm{m}^{-3}$ at the shoal station and $>40 \mathrm{mg} \mathrm{m}^{-3}$ at the channel station (Fig. 3). Phytoplankton biomass declined rapidly after the bloom peak in early April, and chl a concentrations returned to nearly pre-bloom levels by the end of the study period. Dissolved oxygen concentrations were at or below equilibrium with atmospheric oxygen before the bloom, but they became supersaturated during the period of rapid chlorophyll increase and reached maxima of $110 \%$ saturation in the channel surface waters 

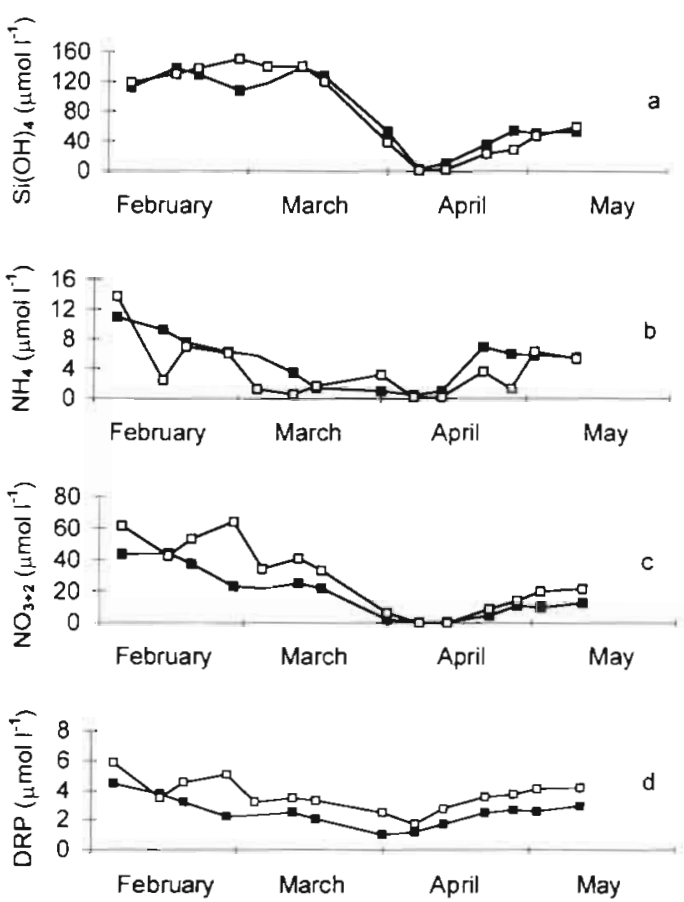

Fig. 4. Nutrient concentrations over time at the shoal ( $\square$ ) and channel ( $\mathbf{m}$ ) sites during the course of the study to measure benthic nutrient and oxygen fluxes (DRP, phoshate)

and $139 \%$ saturation at the shallow site (Fig. 3). These fluctuations in oxygen concentration show: (1) the enhancement of phytoplankton primary production during the bloom; and (2) that bottom waters are always oxygenated in this estuary. Fig. 3 also indicates the timing of core collection, showing that nutrient-flux measurements were made on 5 dates before the bloom began, four dates during the period of high phytoplankton biomass and on 4 dates after the bloom cycle was completed. Near-bottom water temperature at the channel site varied between 12.2 and $18.4^{\circ} \mathrm{C}$ during the study.

Diatoms (especially Coscinodiscus radiatus, Cyclotella striata, C. meneghiniana, Thalassionema decipiens) were dominant components of the spring bloom community in the channel. Cryptophyceae (Cryptomonas spp. and Rhodomonas spp.) were most abundant after the bloom. Estimates of total cell biovolume reached peaks in early April of $2.6 \times 10^{7}$ and $9.1 \times$ $10^{6} \mathrm{um}^{3} \mathrm{ml}^{-1}$ in the channel surface and bottom samples. At the shoal station, the phytoplankton population was composed of diatoms ( $T$. decipiens and $T$. leptopus) and Cryptophyceae (Rhodomonas salina and Teleaulax acuta) during the bloom.

Dissolved inorganic nutrient concentrations fluctuated during the course of the study, and all nutrient species followed the same general pattern of high concentration during late winter, declining concentrations (or depletion) during the bloom, and then increasing concentrations after the bloom (Fig. 4). Silicate concentrations (maximum $140 \mathrm{\mu mol} \mathrm{I}^{-1}$ ) declined to near-zero in mid April, and then increased to $60 \mu \mathrm{mol} \mathrm{l}^{-1}$ after the bloom ended. The concentration of DIN $\left(\mathrm{NH}_{4}+\mathrm{NO}_{2}+\right.$ $\mathrm{NO}_{3}$ ) was maximum $\left(40\right.$ to $\left.80 \mu \mathrm{mol}^{-1}\right)$ in February and decreased to detection limits at both stations just after the bloom peak. Then, the DIN concentrations increased to $\sim 20 \mu_{\mathrm{mol}} \mathrm{r}^{-1}$. We observed a continual decrease of DRP during February and March (minimum concentrations were $\sim 1$ to $2 \mu \mathrm{mol} \mathrm{l}^{-1}$ ), and then an increase in DRP during the post-bloom period. DRP was consistently about $1 \mathrm{umol}^{-1}$ higher at the shallow site than the deep site (Fig. 4d).

\section{Sediment characteristics}

Sediments at both sites include fine-grained to muddy sediments with a porosity of $0.81 \pm 0.01$ (channel) and $0.60 \pm 0.02$ (shoal), averaged over the study period ( 45 replicates). Benthic chl a contents are compared to integral water-column chlorophyll in Fig. 5 (pelagic biomass was calculated as water depth multiplied by the mean chl a concentration in the surface and bottom water samples). Chl a content of the sediments (BenChl) was very low at both sites until midMarch, when phytoplankton pigments appeared in the surface sediments with highest values at the channel station, about $2 \mathrm{wk}$ after the peak of the phytoplankton bloom (Fig. 5). Surface sediments at the shoal station had a mean chl a concentration of $43 \mathrm{mg} \mathrm{m}^{-2}$, compared to the channel station where a background value of 150 and maximum chl a concentration of $335 \mathrm{mg} \mathrm{m}^{-2}$ was observed. Sediment pheopigments were less variable during the study period, and mean pheopigment concentrations were 477 and $226 \mathrm{mg} \mathrm{m}^{-2}$

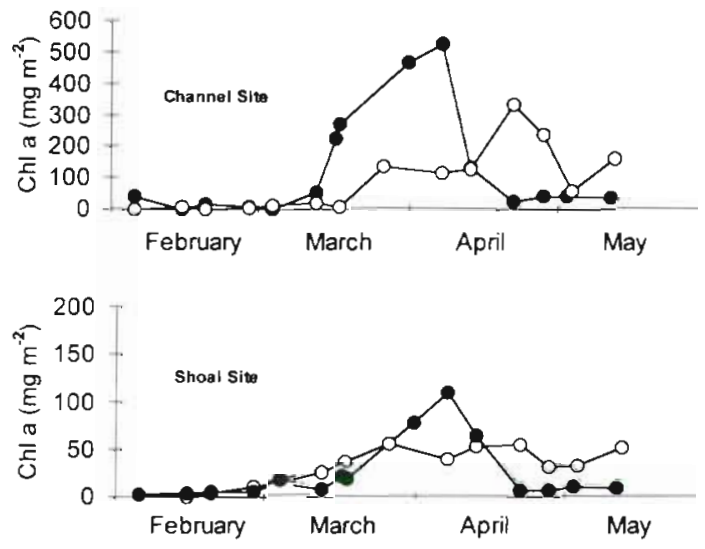

Fig. 5. Time series of phytoplankton biomass (as $\mathrm{chl}$ a) at the channel site and shoal site. Each panel shows the changing concentrations of chl $a$ in the upper sediments $(0)$ and the integrated chl a concentration in the overlying water column ( 
respectively for the channel and shoal stations. Biogenic silica (BSi) in the surface sediments did not vary significantly over the study period, but there were consistent differences between stations: mean BSi (as $\mathrm{SiO}_{2}$ ) was $7.1 \%$ of sediment weight at the channel station but only $2.4 \%$ of sediment weight at the shoal station. No clear signal of enhanced BSi content of sediments was observed following the diatom-dominated bloom and deposition of phytoplankton biomass (pigments) onto the sediment surface.

Macrobenthos density varied between 1 and 200 and between 1 and 1200 ind. core ${ }^{-1}$ respectively at the shoal and channel stations. Bivalves and polychaetes represented equally the macrobenthos population weight during the pre-bloom period. After the bloom, macrobenthos density increased significantly at the channel station because of the recruitment and growth of mollusks (mainly Potamocorbula amurensis and to a lesser extent Musculista senhousia) and the amphipod Ampelisca abdita. At the end of the study period, the mean abundance of $P$, amurensis juveniles was $58000 \mathrm{~m}^{-2}$ at the channel site, representing a wet weight of $710 \mathrm{~g} \mathrm{~m}^{-2}$. At the shoal station, the increase in macrobenthos density was less pronounced $\left(8400 \mathrm{~m}^{-2}\right.$ and $40 \mathrm{~g} \mathrm{~m}^{-2}$ respectively for the number of $P$. amurensis juveniles and corresponding wet weight).

\section{Nutrient and oxygen fluxes}

Nutrient fluxes showed different patterns of variability at the 2 study sites. Before the peak of the bloom, benthic Si fluxes were around 100 and $30 \mu \mathrm{mol} \mathrm{m} \mathrm{m}^{-2} \mathrm{~h}^{-1}$ for the channel and shoal stations respectively. Benthic Si fluxes increased at both sites during the period of chlorophyll increase in the overlying water. The fluxes were significantly different after the bloom period, with higher Si fluxes measured at the channel station (maximum $400 \mu \mathrm{mol} \mathrm{m} \mathrm{m}^{-2} \mathrm{~h}^{-1}$ ) compared to the shoal station $\left(200 \mu \mathrm{mol} \mathrm{m} \mathrm{m}^{-2} \mathrm{~h}^{-1}\right.$ ) (Fig. 6a). Nitrate fluxes also varied both spatially and temporally. Before the bloom, a net consumption of $\mathrm{NO}_{3}$ was measured at the shoal station (maximum rate $-18 \mu \mathrm{mol} \mathrm{m}^{-2} \mathrm{~h}^{-1}$ ), whereas a positive flux of $\mathrm{NO}_{3}$ was observed at the channel Station (Fig. 6b). After the bloom peaked, the shoal sediments began to release nitrate into the water column (maximum rate $8 \mu \mathrm{mol} \mathrm{m} \mathrm{m}^{-2} \mathrm{~h}^{-1}$ ), and highest fluxes were observed at the channel station (maximum $87 \mu \mathrm{mol} \mathrm{m} \mathrm{m}^{-2} \mathrm{~h}^{-1}$ ) at the end of the study period. Ammonium fluxes were negative at the channel station before the bloom, but became positive during the bloom, with highest values observed in mid- to late April $\left(139 \mu \mathrm{mol} \mathrm{m} \mathrm{m}^{-2} \mathrm{~h}^{-1}\right.$ ) (Fig. 6c). At the shoal station, ammonium behaved similarly to nitrate but with fluxes
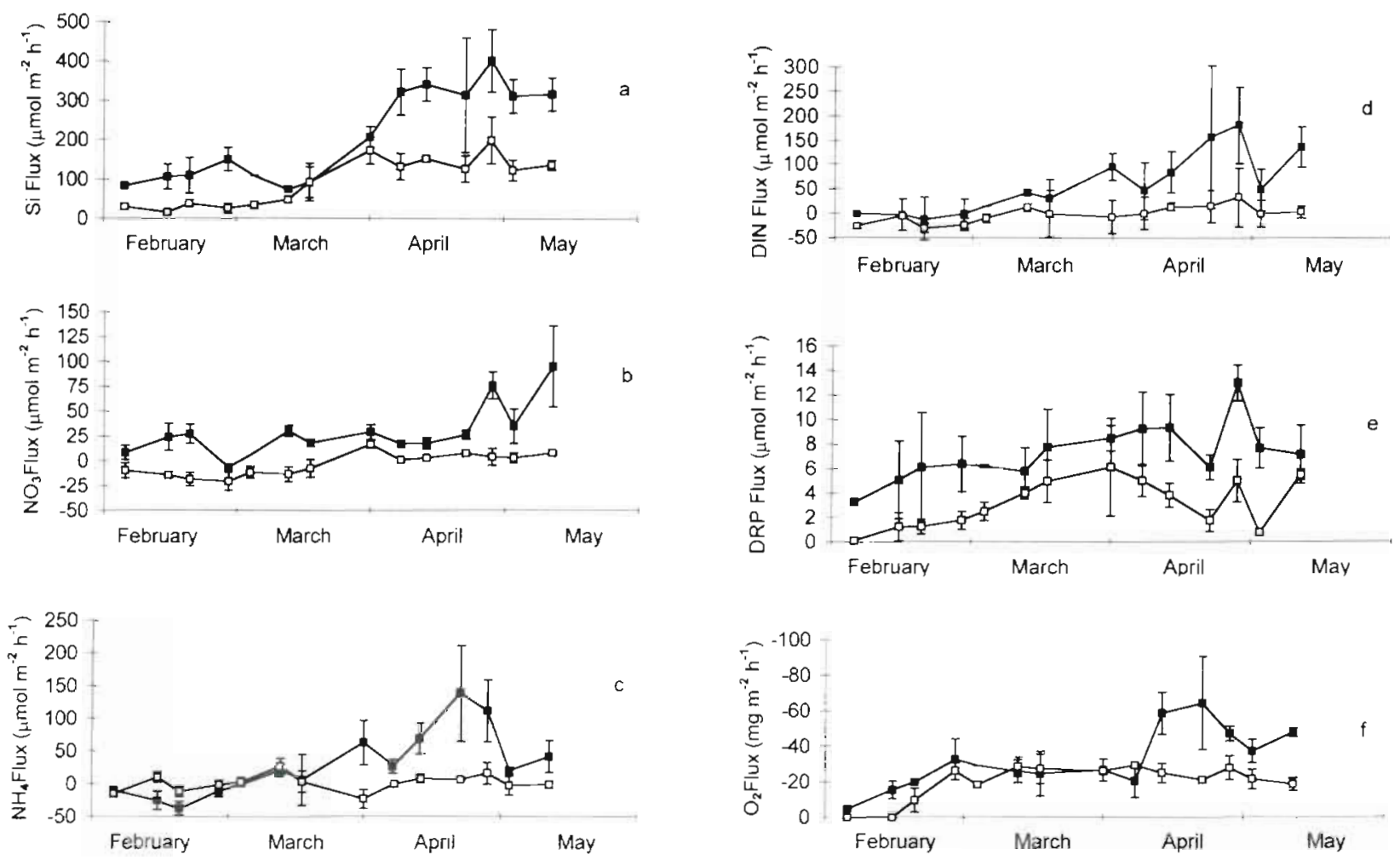

Fig. 6. Nutrient and oxygen fluxes at the shoal ([]) and channel (w) sites during the period February to May 1996 . Values are means from triplicate cores, and error bars show standard deviations 
twice as high (17 compared to $8 \mu \mathrm{mol} \mathrm{m} \mathrm{m}^{-2} \mathrm{~h}^{-2}$ ). Considering DIN flux as the sum of nitrate, nitrite and ammonia fluxes, we measured a net balance at the channel station and a net consumption of DIN at the shoal station before the spring bloom began. As the bloom developed, DIN fluxes became positive and began to increase until after the bloom collapsed, when highest rates were measured at the channel station (Fig. 6d). DRP fluxes were always positive, and the weekly fluctuations were similar at the 2 stations (Fig. 6e), although the DRP flux was consistently higher (mean difference of $4.9 \mu \mathrm{mol} \mathrm{m}^{-2} \mathrm{~h}^{-1}$ ) at the channel site than at the shoal site. Mean benthic oxygen fluxes varied between 0 and $-35 \mathrm{mg} \mathrm{O}_{2} \mathrm{~m}^{-2} \mathrm{~h}^{-1}$ until the beginning of the bloom perod, with no consistent inter-site difference (Fig. 6f). After the bloom peak in early April, the benthic oxygen fluxes increased significantly at the channel station, reaching a maximum of $-64 \pm$ $26 \mathrm{mg} \mathrm{O}_{2} \mathrm{~m}^{-2} \mathrm{~h}^{-1}$. No clear signal of enhanced oxygen consumption was measured at the shoal station, even during the period of elevated chlorophyll concentration.

\section{DISCUSSION}

The first goal of the present study was to measure and describe the system-level responses of nutrient cycling to a phytoplankton bloom, and to determine if the bloom-induced responses in an estuary follow the same patterns observed in controlled mesocosm experiments. The series of chlorophyll measurements (Fig. 3) shows that the 1996 spring bloom in South San Francisco Bay provided an ideal natural experiment comprising: a pre-bloom control period of low algal biomass; a month-long period of rapid production and biomass accumulation; and a post-bloom period of recovery from the bloom-induced changes in nutrient cycling. The weekly sampling showed that nutrient fluxes at the sediment-water interface changed rapidly in direction and magnitude during the transitions between these periods. In the deep channel domain of the estuary, we can characterize these 3 periods as follows:

(1) The pre-bloom phase (February to mid-March) was a period of low phytoplankton biomass (integrated chl $a<50 \mathrm{mg} \mathrm{m}^{-2}$; Fig. 5), low primary productivity (gross productivity $<200 \mathrm{mg} \mathrm{C} \mathrm{m}^{-2} \mathrm{~d}^{-1}$; Caffrey et al. 1998), negligible chl a content in the surficial sediments, very large stocks of dissolved inorganic $N, P$ and Si (Fig. 4), and generally small rates of benthicpelagic exchange of $\mathrm{O}_{2}, \mathrm{~N}, \mathrm{P}$ and $\mathrm{Si}$ (Fig. 6). The large stocks of dissolved inorganic nutrients were derived from point-source and diffuse inputs (Hager \& Schemel 1996), and were essentially unaffected by low rates of algal uptake. Internal processes of nutrient recycling probably contributed little to the maintenance of the high nutrient concentrations, because benthic sources of nutrients were small at this time.

(2) The bloom phase (mid-March to mid-April) was a period of rapid changes in all these attributes. Gross primary productivity averaged $1760 \mathrm{mg} \mathrm{C} \mathrm{m}^{-2} \mathrm{~d}^{-1}$ (Caffrey et al. 1998), chl a biomass increased to $>500 \mathrm{mg}$ $\mathrm{m}^{-2}$ in the water column (Fig. 5), and the chl a content of the sediments increased to about $100 \mathrm{mg} \mathrm{m}^{-2}$. The initial stocks of dissolved inorganic $N\left(>50 \mu \mathrm{mol} \mathrm{l}^{-1}\right)$ and $\mathrm{Si}\left(>120 \mu \mathrm{mol} \mathrm{I}^{-1}\right.$ ) were completely depleted and the stock of DRP was reduced from $>4$ to $<1 \mu$ mol $I^{-1}$ during the bloom phase. Therefore, this was a period of rapid phytoplankton conversion of inorganic $N, P$ and Si into particulate forms of these elements. A fraction of the newly produced biomass sank and was incorporated into the surficial sediments during the bloom phase (Fig. 5). Benthic fluxes of $\mathrm{NH}_{4}, \mathrm{NO}_{3}, \mathrm{DRP}, \mathrm{Si}$ and $\mathrm{O}_{2}$ were all higher than during the pre-bloom phase (Fig. 6).

(3) The post-bloom phase (mid-April to mid-May) was a period of small phytoplankton biomass but high chl a content of the surface sediments $\left(>300 \mathrm{mg} \mathrm{m}^{-2}\right)$, reduced primary productivity $\left(-400 \mathrm{mg} \mathrm{C} \mathrm{m}^{-2} \mathrm{~d}^{-1}\right)$, increased concentrations of dissolved inorganic $N, P$ and $\mathrm{Si}_{1}$ and continued elevation of the benthic fluxes of $\mathrm{O}_{2}, \mathrm{~N}$ and Si. Phytoplankton biomass declined rapidly in mid-April, presumably in part as a response to nutrient $(N, S i)$ limitation when these elements were depleted. During this post-bloom phase, the chl a concentration of the sediments was much higher than the integrated chl a content of the water column (Fig. 5), suggesting rapid sedimentation and incorporation of phytoplankton biomass into the surficial sediments. This rapid translocation of chlorophyll biomass from the water column to the benthos was followed by a gradual recovery of the stocks of dissolved inorganic N, P and Si (Fig. 4), and continued high rates of release of these elements from the sediments (Fig. 6).

The strong covariability of algal and nutrient dynamics corroborates that phytoplankton production is a driving force of rapid change in the cycling of $\mathrm{N}, \mathrm{P}$ and $\mathrm{Si}$, including changes in the partitioning of these elements between dissolved and particulate phases and between the pelagic and benthic compartments, as suggested by mesocosm experiments (Kelly \& Nixon 1984, Hansen \& Blackburn 1992, Andersen 1996). Each phase of the bloom cycle represents a different balance between the key processes of nutrient cycling: the prebloom phase represents a dominance of nutrient sources over sinks; the bloom phase represents a dominance of sinks (phytoplankton uptake) over sources, with a conversion of nutrients from the dissolved inorganic to particulate form; the post-bloom phase is one 
of rapid recovery as the phytoplankton biomass is translocated from the water column to the sediments, and as benthic mineralization of that biomass returns inorganic nutrients back to the water column.

A second goal of this study was to compare the patterns of nutrient cycling in deep and shallow estuarine habitats where, presumably, the strength of benthic-pelagic coupling differs. Results from this comparison show that some prominent features of nutrient cycling in the channel were not observed at the shallow site. Our results did show similar patterns of coupled algae-nutrient variability at the shallow and deep study sites, with similar timing of the spring bloom and nearly identical patterns of depletion and recovery of dissolved N, P and Si (Fig. 4). However, the benthic responses to the bloom cycle were very different at the 2 sites. There was a relatively small signal of algal deposition at the shallow site (Fig. 5). Consequently, there was only a small signal of enhanced benthic metabolism (as oxygen consumption, Fig. 6) and the response of benthic nutrient flux was damped at the shallow site. The peak Si fluxes were 3 times smaller than at the channel site, and the $\mathrm{NH}_{4}$ fluxes were stable at the shallow site while they varied from negative to large positive rates at the channel site (Fig. 6). Therefore, even though the pelagic systems behaved nearly identically at the deep and shallow study sites, the benthic systems had different responses to the dynamics of the pelagic system. This suggests that the nature of benthic-pelagic coupling differs between the shallow and deep regimes of South San Francisco Bay.

Differences between the shallow- and deep-site benthic systems could partly be a result of physical processes that drive a net (tidally averaged) transport of shoal-produced phytoplankton biomass into the channel, where that biomass sinks and accumulates in the channel sediments. This focusing mechanism has been observed in other coastal systems, such as fjords (Noji et al. 1993), where organic matter accumulates in deep regions. Consistent with this hypothesis are: (1) the 10-fold higher accumulation of chl $a$ in the channel sediments compared to the shoal sediments (Fig. 5) and (2) oxygen balances (Caffrey et al. 1998) which show that the shallow domain was net autotrophic (i.e. a net source of phytoplankton biomass) while the deep domain was net heterotrophic (a net sink for phytoplankton biomass) during this study period. Other contrasts suggest that the benthos of the deep and shallow domains behave as distinct biogeochemical systems: biogenic silica content was consistently higher in the channel sediments $\left(7.1 \% \mathrm{SiO}_{2}\right)$ than in the shoal sediments $\left(2.4 \% \mathrm{SiO}_{2}\right)$; and DRP fluxes were consistently higher from the channel sediments than the shoal sediments (Fig. 6). All of these differences are consistent with the concept of net transport and deposition of (diatom-dominated) phytoplankton biomass from the shallow regions into the deep channels. Therefore, we must use care in extrapolating results of mesocosm experiments to estuaries where the patterns of coupled algae-nutrient dynamics are influenced by horizontal transports. In particular, the benthic compartments of estuaries may not receive inputs from locally produced organic matter. Horizontal transports can lead to spatial decoupling of the functions of production and mineralization; this decoupling is difficult to simulate with mesocosm experiments.

Other differences between the shallow and deep benthic systems cannot be explained by horizontal transports of organic matter. Our measurements give several indications that denitrification is a stronger influence on $\mathrm{N}$ cycling at the shallow site than the deep site. For example, plots of $\mathrm{NH}_{4}$ flux against total DIN flux (Fig. 7) show that most shoal-site measurements fall on or above the 1:1 line, indicating that the benthic flux of $\mathrm{NO}_{3}+\mathrm{NO}_{2}$ was near zero or negativea strong indicator of net loss to denitrification in the shallows. Most of the channel-site measurements fall below the 1:1 line, indicating consistent positive fluxes of $\mathrm{NO}_{3}+\mathrm{NO}_{2}$. A second indicator of differential $N$ cycling is evident in a comparison of the stoichiometries of Si and $\mathrm{N}$ fluxes (determined by Type 2 regression, Laws \& Archie 1981). The mean Si:N flux at the channel site was 20:11 compared to 20:6 for the shoal site, again indicating significantly lower $N$ release relative to $\mathrm{Si}$ release from sediments at the shallow site. These differences in $\mathrm{N}$ cycling could be a result of spatial differences in sediment properties, including porosity and its influence on redox conditions and the depths of the zones of nitrification and denitrification (Hammond et al. 1985, Ruardij \& van Raaphorst 1995).

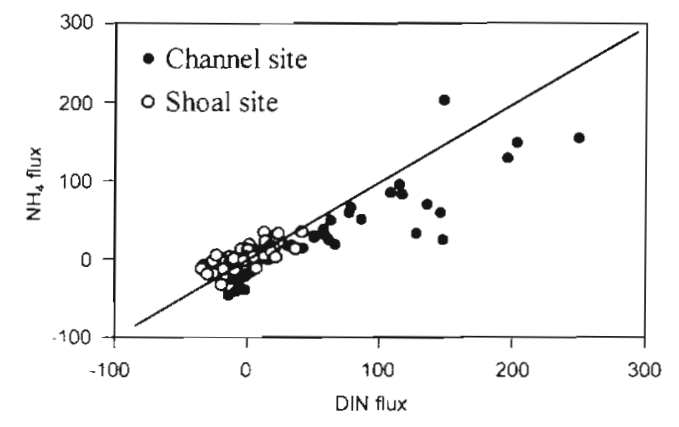

Fig. 7. Benthic fluxes of $\mathrm{NH}_{4}$ against benthic fluxes of DīN, pooling measurements at the channel site $(\bullet)$ and shallow site (O). Data points below the 1:1 line indicate that the sediments are a source of $\mathrm{NO}_{3} / \mathrm{NO}_{2}$, data points above the line indicate that the sediments are a sink for these $N$ species, and that losses to denitrification are inportant 


\section{Benthic supply versus phytoplankton demand for nutrients}

Release of nutrients from the sediments can supply a substantial fraction of the nutrient requirements for primary producers in coastal areas (e.g. Dollar et al. 1991, Giblin et al. 1997). If this is true on an annual scale, then how does the balance between benthic supply and phytoplankton demand change on a weekly scale during a bloom event? We calculated a ratio of benthic nutrient flux to primary production requirements for the total South Bay, weighting the nutrient fluxes by the respective surface area of the shallows $(80 \%)$ and deep channel domains $(20 \%)$. The weighted South Bay-wide fluxes were divided by the nutrient requirements for primary production, using productivity estimates reported by Caffrey et al. (1998) and phytoplankton nutrient demand based on Redfield ratios. Fig. 8 shows the time evolution of these ratios, which can be divided into the pre-bloom, bloom, and post-bloom phases. During the pre-bloom period, the net flux of DIN was negative so the sediments contributed nothing to the phytoplankton $\mathrm{N}$ demand. Silicate and phosphate releases from the sediments were variable and satisfied between 30 and $>100 \%$ of the phytoplankton requirements for these elements.

During the bloom, the ratios were less variable and represented a mean of 20,16 and $9 \%$ respectively for $\mathrm{Si}, \mathrm{P}$ and $\mathrm{N}$. Although benthic fluxes were enhanced for all 3 nutrient elements during the bloom, the benthic source was clearly not sufficient to fuel the measured rates of biomass accumulation and production. Therefore, the potential size of the spring bloom in South San Francisco Bay appears to be set by the size of the winter nutrient stocks plus the rate of external loading during the bloom phase. After the bloom, the supply:demand ratios increased again for $\mathrm{Si}(60$ to $110 \%$ ), DRP ( 20 to $33 \%$ ) and DIN (14 to $47 \%$ ).

The weekly variation of nutrient supply from sediments relative to pelagic demand shows that lowest percent contributions occurred when demand was high-i.e. during the bloom. Cowan \& Boynton (1996) similarly concluded that nutrient fluxes from Chesapeake Bay sediments supply only a small fraction of the phytoplankton requirement when production rates are high. For Mobile Bay sediment, Cowan et al. (1996) did not observe a clear seasonal pattern of the supply:demand ratio because they did not observe a strong seasonal pattern of productivity. Over our $15 \mathrm{wk}$ measurements, a mean percent contribution can be estimated as 42,20 and $8 \%$ for $\mathrm{Si}, \mathrm{DRP}$ and DIN demand respectively. The DIN supply:demand ratio is in the lower range of values reported for other coastal systems (Nixon \& Pilson 1983, Kemp \& Boynton 1984,

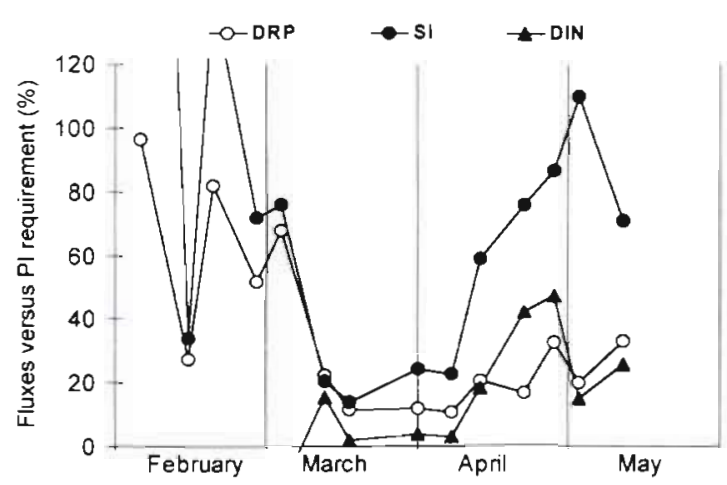

Fig. 8. Time series of the contribution of benthic nutrient fluxes to the requirement for phytoplankton primary production, estimated for the entire South San Francisco Bay (see 'Benthic supply versus phytoplankton demand for nutrients')

Boynton \& Kemp 1985), but is consistent with previous measurements in South San Francisco Bay (Caffrey et al. 1996).

\section{An empirical model of sediment nutrient fluxes}

During the course of this study we measured large variability in the sediment nutrient fluxes at the 2 sites in South San Francisco Bay. Si fluxes ranged from 16 to $400 \mu \mathrm{mol} \mathrm{m} \mathrm{m}^{-2} \mathrm{~h}^{-1}$ (a factor of 25); DIN fluxes ranged from -30 to $+75 \mu \mathrm{mol} \mathrm{m}^{-2} \mathrm{~h}^{-1}$; and DRP fluxes ranged from 0 to $13 \mu \mathrm{mol} \mathrm{m} \mathrm{m}^{-2} \mathrm{~h}^{-1}$. Can the large variability in benthic nutrient flux be explained, in a statistical sense, with empirical functions that capture the underlying mechanisms of this variability? Some mechanistic models (e.g. Hammond et al. 1985) describe benthic nutrient flux as the combination of diffusive processes that transport solutes through the interstitial waters, and advective processes that transport solutes across the sediment-water interface. Both processes scale with the concentration gradients of nutrients within the porewaters and between the porewaters and overlying water. Nutrient fluxes across the sediment-water interface can be described with Fick's First Law for sediments, by treating all mixing processes in terms of a diffusion coefficient (Berner 1980). If we ignore porewater burial, then

$$
J^{*}=-\phi D_{\mathrm{T}}(\mathrm{d} C / \mathrm{d} x)_{0}
$$

where $J^{*}$ is the total flux from all advective and diffusive processes; the effective diffusion coefficient $D_{\mathrm{T}}$ $\left(\mathrm{m}^{2} \mathrm{~h}^{-1}\right)$ includes the combined effects of all transport processes such as molecular diffusion, advection and bioirrigation from the burrowing, feeding and excretion activities of infauna (Ullman \& Aller 1982, Webster et al. 1996); $\phi$ is sediment porosity (dimensionless); and 
$(\mathrm{d} C / \mathrm{d} x)_{0}$ is the vertical concentration gradient of dissolved nutrient at the sediment-water interface (where depth $x=0$ ). We can use Eq. (1) to develop a simple empirical expression that describes much of the variability of nutrient fluxes in South San Francisco Bay. First, we describe the vertical gradient $(\mathrm{d} C / \mathrm{d} x)_{0}$ as a linear function of the difference in nutrient concentration between the upper porewaters $C_{\mathrm{p}}$ and the overlying water $C_{0}$, following Callender \& Hammond (1982) and Bolalek \& Graca (1996):

$$
(\mathrm{d} C / \mathrm{d} x)_{0}=\left(C_{0}-C_{\mathrm{p}}\right) / z
$$

where $z$ is a length scale (which can be interpreted as the depth below the sediment surface at which dissolved nutrients readily exchange with the overlying water). Eq. (1) can then be rewritten as:

$$
J^{*}=\left(-\phi D_{\top} / z\right)\left(C_{0}-C_{\mathrm{p}}\right)=-\phi V\left(C_{0}-C_{\mathrm{p}}\right)
$$

The term $V\left(=D_{\mathrm{T}} / z\right)$ is in meters per hour, and it can be interpreted as an exchange coefficient, analogous to the piston velocity used to describe gas exchange across the air-sea interface (Liss \& Slater 1974).

In our study we measured $J^{*}, \phi$ and $C_{0}$, and we estimated the quantities $V$ and $C_{p}$ by least-squares regression. We did this in 2 ways, first by assuming that the surficial porewater concentration $C_{n}$ is constant (Model I = Eq. 3), and second by assuming that $C_{\mathrm{p}}$ varies (linearly) with the concentration of labile organic matter in/on the surficial sediments, indexed as the chl a concentration (BenChl) in the upper $3 \mathrm{~cm}$ (let $C_{p}=a+b B e n C h l$ ). In this second approach (Model II), we describe nutrient fluxes with the function:

$$
\begin{aligned}
& J^{*}=-\phi V\left(C_{0}-a-b \text { BenChl }\right) \\
& J^{*}=-\phi V\left(C_{0}-a\right)+\phi V b \text { BenChl }
\end{aligned}
$$

Eqs. (3 \& 4) reduce the coupled processes of diagenetic reactions and physical transports into a few terms, but they are consistent with features of benthic nutrient flux often observed in shallow coastal systems: (1) benthic nutrient fluxes are proportional to sediment porosity (Berner 1980); (2) changes in the magnitude and direction of benthic fluxes covary with changes in nutrient concentration in the water column (Cowan \&
Boynton 1996); and (3) strong correlations are observed between nutrient efflux from sediments and the chlorophyll content of the surficial sediments, an indicator of newly deposited phytodetritus (Cowan et al. 1996). We combined the 27 nutrient flux measurements from the channel and shoal sites, and fitted values of $J^{\bullet}$ to Eqs. (3) \& (4) separately for each nutrient species. The quantities $V, a$, and $b$ were estimated with a quasi-Newton algorithm to determine parameter values that minimize the sum of squared deviations between measured nutrient fluxes and the fluxes calculated with the model equations.

Model I accounts for $74 \%$ of the variance of the benthic flux of silicate and $67 \%$ of the variance of DRP flux in South San Francisco Bay (Table 1). However this simple model does not explain the variability of ammonium or nitrate fluxes. The Model II equation accounts for $84 \%$ of the variance of ammonium flux, but only $42 \%$ of the variance of nitrate flux. Although these equations are purely empirical descriptions of the net effect of many linked processes, they do provide estimates of benthic nutrient flux from a few simple predictor variables: sediment porosity, dissolved nutrient concentration above the sediment-water interface and chlorophyll content of the surficial sediments. These estimates are good for silicate and ammonium flux (Fig. 9), less accurate for DRP flux and unreliable for nitrate

These models might provide some insights into the mechanisms that govern benthic-pelagic exchange of the different nutrient species. Model I includes 1 general (physical) process - transport of dissolved nutrients at a rate proportional to the concentration gradient across the sediment-water interface. For this gradient-driven process, spatial and temporal variability of benthic-pelagic exchange can be explained simply by the spatial variations in sediment porosity and temporal fluctuations of nutrient concentration in the water column. The good agreement between Model I estimates and the measured fluxes of silicate and phosphate suggests that benthic-pelagic exchange of these elements is largely controlled by the gradient-driven process in South San Francisco Bay.

\begin{tabular}{|c|c|c|c|c|c|c|c|}
\hline & \multicolumn{3}{|c|}{ Model I: $J^{\cdot}=-\phi V\left(C_{0}-a\right)$} & \multicolumn{4}{|c|}{ Model Il: $J^{*}=-\phi V\left(C_{0}-a-b\right.$ BenChl $)$} \\
\hline & $V$ & a & $r^{2}$ & $V$ & a & $b$ & $r^{2}$ \\
\hline $\mathrm{Si}$ & 2.21 & 182.60 & 0.74 & 1.53 & 196.50 & 4.39 & 0.84 \\
\hline DRP & 2.28 & 6,30 & 0.67 & 1.94 & 6.51 & 0.05 & 0.71 \\
\hline $\mathrm{NH}_{4}$ & 3.44 & 12.18 & 0.10 & 2.09 & -1.81 & 2.64 & 0.89 \\
\hline $\mathrm{NO}_{3}$ & 0.88 & 46.87 & 0.31 & 0.39 & 46.81 & 4.42 & 0.42 \\
\hline
\end{tabular}

Table 1. Empirical models of benthic nutrient flux $J \cdot$ for silicate, phosphate, ammonium and nitrate, from cores collected at shallow and deep sites in South San Francisco Bay, spring 1996. Adjusted $r^{2}$ shows the fraction of the variance of measured fluxes explained by each model. Values in bold were used to estimate fluxes shown in Fig. 9 
Explicit in Model I is the assumption that porewater concentrations of dissolved Si and P are constant. This assumption may be approximately correct because of adsorption/desorption reactions that buffer the porewater concentrations of Si and DRP. The concept of buffered Si concentrations has a long history (Fanning \& Pilson 1971, Siever \& Woodford 1973, Mayer \& Gloss 1980), and more recent observations show that the equilibrium porewater concentration is a function of temperature (McManus et al. 1995). This temperature effect would be expected to have only a secondary influence in South San Francisco Bay due to the small temperature range (12.2 to $18.4^{\circ} \mathrm{C}$ ) during the course of our study. Nevertheless, inclusion of a temperature effect (McManus et al. 1995) in Eq. (3) improved the fit of measured Si fluxes to Model I $\left(\mathrm{r}^{2}\right.$ increased from 0.74 to 0.84 ), suggesting that some small components of $\mathrm{Si}$ flux could be related to dissolution of freshly deposited frustules (Kamatani 1982). Concentrations of DRP in interstitial waters are also buffered by adsorption/desorption reactions (Sundby et al. 1992, Slomp \& van Raaphorst 1993).

The larger residuals around the Model I fit to DRP fluxes (Fig. 9) could be a result of additional fates for the DRP released: e.g. formation of minerals (Berner 1980, Sundby et al. 1992, Sarazin et al. 1993) or reaction of adsorbed phosphate with particle surfaces, especially those coated with iron oxyhydroxides (e.g. Froelich 1988). Additionally, some P may be lost as dissolved organic phosphorus.

The gradient-driven process alone (Model I) does not explain the variability of $\mathrm{N}$ fluxes (Table 1). The ammonium flux was strongly correlated with benthic chlorophyll concentration and only weakly correlated with ammonium concentration, so the benthic-pelagic exchange of this $\mathrm{N}$ species may be governed primarily by the mineralization rate of algal-derived organic matter (the positive term in Eq. 4; see Hammond et al. 1985). Inclusion of this additional term improves the model fit so that Model II accounts for most $(84 \%)$ of the variance of the ammonium flux. The empirical nature of this model does not help us identify the specific mechanisms of ammonium regeneration and release from sediments. The additional process included in Model II could be interpreted as either: (1) mineralization of bloom-derived phytoplankton biomass
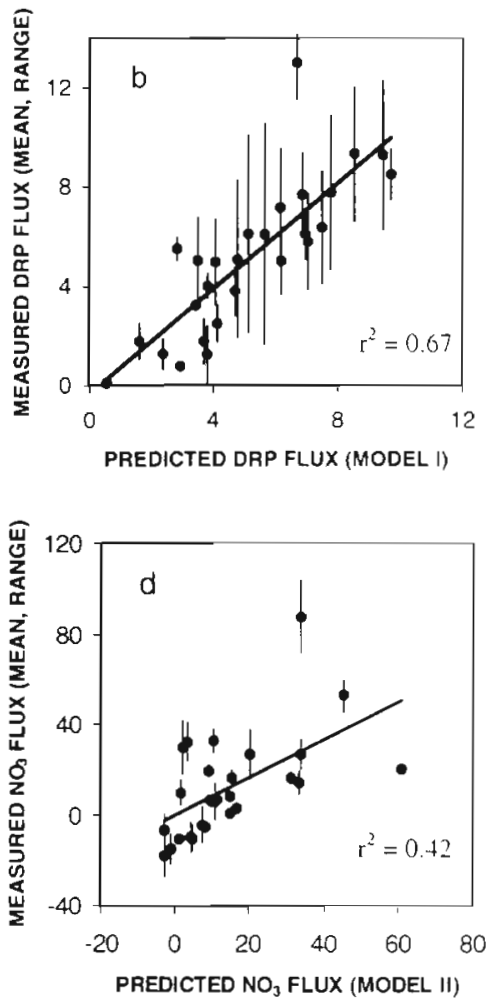

Fig. 9. Individual plots of measured versus estimated fluxes of dissolved inorSi, DRP, $\mathrm{NH}_{4}$ and $\mathrm{NO}_{3}$. Each plot pools the measurements made at the of measurements; vertical lines: range of measurements from incubation of collected at each site. Diagonal lines show linear regressions of measured versus estimated fluxes (see Table 1)

within the sediments, leading to elevated ammonium concentrations in porewaters (leftmost form of Eq. 4), or (2) direct release of ammonium from the mineralization of algal biomass settled onto the sediment surface (rightmost form of Eq. 4). A third, indirect mechanism could be the enhancement of ammonium excretion by the macrofauna in response to pulsed increases of food following the spring bloom (Caffrey 1995). The measured nitrate fluxes in South San Francisco Bay sediments are not well explained by either model (Table 1 . Fig. 9), so additional processes must be considered such as the linked processes of mineralization, nitrification and denitrification (e.g. Ruardij \& van Raaphorst 1995). The additional complexity of nitrogen biogeochemistry suggests that it might be difficult to find simple empirical expressions to completely describe benthic fluxes of nitrate.

\section{Conclusion}

Although the governing processes of benthic exchange vary among nutrient elements, we observed 
Table 2. Correlation coefficients between benthic fluxes of silicate, phosphate, nitrate and ammonium. All correlations are significant $(\mathrm{p}<0.05) ; \mathrm{n}=27$ measurements

\begin{tabular}{|lccc|}
\hline & DRP & $\mathrm{NH}_{4}$ & $\mathrm{NO}_{3}$ \\
\hline $\mathrm{Si}$ & 0.80 & 0.71 & 0.74 \\
$\mathrm{DRP}$ & & 0.56 & 0.70 \\
$\mathrm{NH}_{4}$ & & & 0.49 \\
\hline
\end{tabular}

significant positive correlations between the fluxes of all the nutrients (Table 2). These strong correlations show that release of nutrients from sediments responds to a common source of variability, and in South San Francisco Bay that source of variability is the spring bloom. The models used here provide a simple framework for understanding the linkages between phytoplankton blooms and benthic-pelagic nutrient exchange. Algal blooms work to accelerate gradientdriven processes by depleting nutrient concentrations from the water column (decreasing $C_{0}$ and therefore increasing $J^{\cdot}$ ). This linkage seems to dominate for $\mathrm{Si}$ and $P$ in South San Francisco Bay, where the augmented benthic fluxes around the spring bloom cooccur with the periods of depleted nutrient concentrations in the water column. This same pattern holds for $P$ flux in the Dutch Wadden Sea (van Raaphorst et al. 1988). Algal blooms also promote the delivery of labile organic matter to the sediments where it is mineralized and nitrogen is released from the sediments. This linkage appears to be important for $N$ regeneration in South San Francisco Bay, where the ammonium flux from the sediments is highly correlated with the chlorophyll content of the surficial sediments.

As a final comment we note that these principles of linkage between bloom dynamics and benthic nutrient regeneration are not general. For example in the Skagerrak, Hall et al. (1996) found no correlations among the benthic fluxes of $\mathrm{P}, \mathrm{N}$ and Si. In Mobile Bay most of the variability of nutrient fluxes is correlated with temperature and bottom-water oxygen concentration (Cowan et al. 1996). And in Loch Linnhe, Overnell et al. (1995) measured sediment uptake (not release) of nitrate during the spring bloom. Clearly, the linkages between algal production/deposition and sediment nutrient cycling vary among and within coastal ecosystems, depending on features such as the redox conditions of bottom waters, pathways of mineralization, vertical and horizontal transports of organic matter and geochemical properties of the sediments.

Acknowledgements. This study was supported in part by the USGS Toxic Substances Hydrology Program. During his stay at USGS, C. Grenz was supported by French CNRS and
NATO. We thank Scott Conard, Jody Edmunds, Jim Kuwabara, Jelriza Baylosis, Francis Parchaso, Byron Richards for their assistance in field and laboratory, especially Jane Caffrey for her able assistance and advice during the flux measurements, Oscar Mace for measuring macrobenthos biomass and Richard Dufford for identification and biomass measurements of phytoplankton.

\section{LITERATURE CITED}

Alldredge AL, Gotschalk CC (1989) Direct observations of a mass flocculation of diatom blooms: characteristics, settling velocities and formation of diatom aggregates. DeepSea Res 36:159-171

Andersen FO (1996) Fate of organic carbon added as diatom cells to oxic and anoxic marine sediment microcosm. Mar Ecol Prog Ser 134:225-233

Berner RA (1980) Early diagenesis: a theoretical approach. Princeton University Press, Princeton

Billen G (1978) A budget of nitrogen recycling in North Sea sediments off the Belgian coast. Estuar Coast Mar Sci 7 : $127-146$

Blackburn TH, Henriksen $\mathrm{K}$ (1983) Nitrogen cycling in different types of sediments from Danish waters. Limnol Oceanogr 28:477-493

Bolalek J, Graca B (1996) Ammonia nitrogen at the water-sediment interface in Puck Bay (Baltic Sea). Estuar Coast Shelf Sci 43:767-779

Boynton WR, Kemp WM (1985) Nutrient regeneration and oxygen consumption by sediments along an estuarine salinity gradient. Mar Ecol Prog Ser 23:45-55

Caffrey J (1995) Spatial and seasonal patterns in sediment nitrogen remineralization and ammonium concentrations in San Francisco Bay, California. Estuaries 18:219-233

Caffrey JM, Hammond DE, Kuwabara JS, Miller LG, Twilley RR (1996) Benthic Processes in South San Francisco Bay: The Role of Organic Inputs and Bioturbation. In: Hollibaugh JT (ed) San Francisco Bay: the ecosystem. AAAS Pacific Division, San Francisco, p 425-444

Caffrey JM, Cloern JE, Crenz C (1998) Changes in production and respiration during a spring phytoplankton bloom in San Francisco Bay, California, USA: implications for net ecosystem metabolism. Mar Ecol Prog Ser 172:1-12

Callender E, Hammond DE (1982) Nutrient exchange across the sediment-water interface in the Potomac River Estuary. Estuar Coast Shelf Sci 15:395-413

Cloern JE (1984) Temporal dynamics and ecological significance of salinity stratification in an estuary (South San Francisco Bay, USA). Oceanol Acta 7:137-141

Cloern JE (1996) Phytoplankton bloom dynamics in coastal ecosystems: a review with some general lessons from sustained investigation of San Francisco Bay, California. Rev Geophys $34(2): 127-168$

Cloern JE, Cole BE, Wong RLJ, Alpine AE (1985) Temporal dynamics of estuarine phytoplankton: a case study of San Francisco Bay. Hydrobiologia 129:153-176

Cowan JL, Boynton WR (1996) Sediment-water oxygen and nutrient exchanges along the longitudinal axis of Chesapeake Bay: seasonal patterns, controlling factors and ecological significance. Estuaries 19:562-580

Cowan JLW, Pennock JR, Boynton WR (1996) Seasonal and interannual patterns of sediment-water nutrient and oxygen fluxes in Mobile Bay, Alabama (USA): regulating factors and ecological significance. Mar Ecol Prog Ser 141. 229-245

DeMaster DJ (1981) The supply and accumulation of silica in 
the marine environment. Geochim Cosmochim Acta 45: $1715-1732$

Dollar SJ, Smith SV, Vink SM, Obrebski S, Hollibaugh JT (1991) Annual cycle of benthic nutrient fluxes in Tomales Bay, California, and contribution of the benthos to total ecosystem metabolism. Mar Ecol Prog Ser 79:115-125

Fanning KA, Pilson MEQ (1971) Interstitial silica and $\mathrm{pH}$ in marine sediments: some effects of sampling procedures. Science 173:1228-1231

Fisher TR, Carlson P, Barber R (1982) Sediment nutrient regeneration in three North Carolina estuaries. Estuar Coast Shelf Sci 14:101-116

Froelich PN (1988) Kinetic control of dissolved phosphate in natural rivers and estuaries: a primer on the phosphate buffer mechanism. Limnol Oceanogr 33:649-668

Giblin AE, Hopkinson CS, Tucker J (1997) Benthic metabolism and nutrient cycling in Boston Harbor, Massachusetts. Estuaries 20:346-364

Goedkoop W, Johnson RK (1996) Pelagic-benthic coupling profundal benthic community response to a spring diatom deposition in mesotrophic Lake Erken. Limnol Oceanogr $41(4): 636-647$

Graf G, Bengtsson W, Diesner U, Schulz R, Theede H (1982) Benthic response to sedimentation of a spring phytoplankton bloom: process and budget. Mar Biol 67:201-208

Granéli W, Granéli E (1991) Automatic potentiometric determination of dissolved oxygen. Mar Biol 108:341-348

Hager SW, Schemel LE (1996) Dissolved inorganic nitrogen, phosphorus and silicon in South San Francisco Bay. I. Major factors affecting distribution. In: Hollibaugh JT (ed) San Francisco Bay: the ecosystem. AAAS Pacific Division, San Francisco, p 189-216

Hall POJ, Holby O, Kollberg S, Samuelsson MO (1992) Chemical fluxes and mass balances in a manine fish cage farm. IV. Nitrogen. Mar Ecol Prog Ser 89:81-91

Hall POJ, Hulth S, Hulthe G, Landén A, Tengberg A (1996) Benthic nutrient fluxes on a basin-wide scale in the Skagerrak (north-eastern North Sea). J Sea Res 35: 123-137

Hammond DE, Fuller C, Harmon D, Hartman B, Korosec M, Miller LG, Rea R, Warren S, Berelson W, Hager SW (1985) Benthic fluxes in San Francisco Bay. Hydrobiologia 129: $69-90$

Hansen LS, Blackburn TH (1992) Effect of algal bloom deposition on sediment respiration and fluxes. Mar Biol 112: $147-152$

Hargrave BT (1973) Coupling carbon flow through some pelagic and benthic communities. J Fish Res Board Can 30:1317-1326

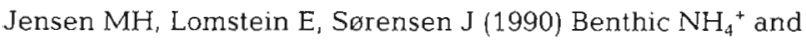
$\mathrm{NO}_{3}{ }^{-}$flux following sedimentation of a spring phytoplankton bloom in Aarhus Bight, Denmark. Mar Ecol Prog Ser $61: 87-96$

Johnson RK, Wiederholm T (1992) Pelagic-benthic coupling - the importance of diatom interannual variability for population oscillations of Monoporeia affinis. Limnol Oceanogr 37:1596-1607

Jørgensen $\mathrm{BB}$ (1983) Processes at the sediment-water interface. In: Bolin B, Cook RB (eds) The major biogeochemical cycles and their interactions. John Wiley \& Sons, Chichester, p $477-515$

Kamatani A (1982) Dissolution rates of silica from diatoms decomposing at various temperatures. Mar Biol 68:91-96

Kelly JR, Nixon SW (1984) Experimental studies of the effect of organic deposition on the metabolism of a coastal marine bottom community. Mar Ecol Prog Ser 17:157-169

Kemp WM, Boynton WR (1984) Spatial and temporal coupling of nutrient inputs to estuarine primary production: the role of particulate transport and decomposition. Bull Mar Sci 35(3):522-535

Koop K, Boynton WR, Wulff F, Carman R (1990) Sedimentwater oxygen and nutrient exchanges along a depth gradient in the Baltic Sea. Mar Ecol Prog Ser 63:65-77

Koseff JR, Holen JK, Monismith SG, Cloern JE (1993) Effects of vertical mixing and benthic grazing on phytoplankton populations in shallow, turbid estuaries. J Mar Res 51. 843-868

Laws EA, Archie JW (1981) Appropriate use of regression analysis in marine biology. Mar Biol 65:13-16

Liss PS, Slater PG (1974) Flux of gases across the air-sea interface. Nature 247:181-184

MacIntyre HL, Cullen JJ (1996) Primary production by suspended and benthic microalgae in a turbid estuary: timescales of variability in San Antonio Bay, Texas. Mar Ecol Prog Ser 145:245-268

Marcus NH, Boero F (1998) Minireview: the importance of benthic-pelagic coupling and the forgotten role of live cycles in coastal aquatic systems. Limnol Oceanogr 43(5): $763-768$

Mayer LM, Gloss SP (1980) Buffering of silica and phosphate in a turbid river. Limnol Oceanogr 25(1):12-22

McManus J, Hammond DE, Berelson WM, Kilgore TE, DeMaster DJ, Ragueneau OG, Collier RW (1995) Early diagenesis of biogenic opal: dissolution rates, kinetics, and paleoceanographic implications. Deep-Sea Res II 42 : $871-903$

Miller-Way T, Twilley RR (1996) Theory and operation of continuous flow systems for the study of benthic-pelagic coupling. Mar Ecol Prog Ser 140:257-269

Nixon SW (1981) Remineralization and nutrient cycling in coastal marine ecosystems. In: Neilson BJ, Cronin LE (eds) Estuaries and nutrients. Humana Press, Clifton, p 111-138

Nixon SW, Pilson ME (1983) Nitrogen in estuarine and coastal marine ecosystems. In: Carpenter EJ Capone DG (eds) Nitrogen in the Maine environment. Academic Press, New York, p 565-648

Nixon SW, Oviat CA, Garber J, Lee V (1976) Diel metabolism and nutrient dynamics in a salt marsh embayment. Ecology $57: 740-750$

Noji TT, Joji CIM, Barthel KG (1993) Pelagic-benthic coupling during the onset of winter in a northern Norwegian fjord. Carbon flow and fate of suspended particulate matter. Mar Ecol Prog Ser 93:89--99

Olesen M, Lundsgaard C (1995) Seasonal sedimentation of autochthonous material from the euphotic zone of a coastal system. Estuar Coast Shelf Sci 41:475-490

Overnell J, Edwards A, Grantham BE, Harvey SM, Jones JW, Leftley $J W$, Smallman DJ (1995) Sediment-water coupling and the fate of the spring phytoplankton bloom in Loch Linnhe, a Scottish fjordic sea-loch. Sediment processes and sediment-water coupling. Estuar Coast Shelf Sci 41 . $1-19$

Ruardij P, van Raaphorst W (1995) Benthic nutrient regeneration in the ERSEM ecosystem model of the North Sea Neth J Sea Res 33:453-483

Sarazin G, Gaillard JF, Philippe L, Rabouille C (1993) Organic matter mineralization and nutrient fluxes at the sediment-water interface of a eutrophic lake (Aydat Lake, Puy de Dome, France). Chem Geol 107:471-476

Siever R, Woodford N (1973) Sorption of silica by clay minerals. Geochim Cosmochim Acta 37:1851-1880

Slomp CP, van Raaphorst W (1993) Phosphate adsorption in oxidized marine sediments. Chem Geol 107:477-480 
Sondergaard M, Kristensen P, Jeppesen E (1992) Phosphorus release from resuspended sediment in the shallow and wind-exposed Lake Arreso, Denmark. Hydrobiologia 228: 91-99

Strickland JDH, Parsons TR (1972) A practical handbook of seawater analysis, 2nd edn. Bull Fish Res Board Can 167: $21-26$

Sundby B, Gobeil C, Silverberg N, Mucci A (1992) The phosphorous cycle in coastal marine sediments. Limnol Oceanogr 37:1129-1145

Taylor DI (1992) The influence of upwelling and short-term changes in concentrations of nutrients in the water column on fluxes across the surface of a salt marsh. Estuaries 15: $68-74$

Tiselius P, Kuylenstierna M (1996) Growth and decline of a diatom spring bloom: phytoplankton species composition, formation of marine snow and the role of heterotrophic dinoflagellates. J Plankton Res 18(2):133-155

Editorial responsibility: Otto Kinne (Editor), Oldendorf/Luhe, Germany
Trimmer M, Nedwell DB, Sivyer DB, Malcolm SJ (1998) Nitrogen fluxes through the lower estuary of the river Great Ouse, England: the role of the bottom sediments. Mar Ecol Prog Ser 163:109-124

Tuominen L, Kairesalo T, Hartikainen H, Tallberg P (1996) Nutrient fluxes and microbial activity in sediment enriched with settled seston. Hydrobiologia 335:19-31

Ullman WJ, Aller RC (1982) Diffusion coefficients in nearshore marine sediments. Limnol Oceanogr 27:552-556

van Raaphorst W, Ruardij P, Brinkman AG (1988) The assessment of benthic phosphorus regeneration in an estuarine ecosystem model. Neth J Sea Res 22:23-36

Walters RA, Cheng RT, Conomos TJ (1985) Time scales of circulation and mixing processes of San Francisco Bay waters. Hydrobiologia 129:13-36

Webster IT, Norquay SJ, Ross FC, Wooding RA (1996) Solute exchange by convection within estuarine sediments. Estuar Coast Shelf Sci 42:171-183

Submitted: July 13. 1999; Accepted: October 26, 1999 Proofs received from author(s): April 5, 2000 